В. М. Запорожан, М. М. Каштальян, О. В. Чернецька Одеський національний медичний університет

\title{
СУЧАСНІ ПІДХОДИ ДО ОСВІТНЬОГО ПРОЦЕСУ $З$ ПІДГОТОВКИ ВИСОКОПРОФЕСІЙНИХ ФАХІВЦІВ
}

\author{
V. M. Zaporozhan, M. M. Kashtalian, O. V. Chernetska \\ Odessa National Medical University \\ MODERN APPROACHES TO EDUCATIONAL PROCESS OF HIGHLY \\ PROFESSIONAL SPECIALISTS TRAINING
}

\footnotetext{
У роботі висвітлено основні пріоритети розвитку сучасної медичної освіти. Найбільша увага приділяється якісній підготовці лікарів шляхом використання новітніх інноваційних технологій в освітньому процесі.
}

Ключові слова: освітній процес; підготовка лікарів; інноваційні технології.

The paper deals with principle priorities of modern medical education development. The article focuses on the high-quality training for doctors by means of modern innovation technologies improving into the process of education.

Key words: educational process; training of doctors; innovative technologies.

Вступ. Завдання, що стоять перед вищою медичною школою у ході розбудови галузі, можуть бути вирішені тільки за умови впровадження сучасних інноваційних технологій для якісної підготовки фахівців, розвитку віртуальної освіти та самоосвіти медиків, подальшого створення університетських клінік та лікарень.

Мета роботи - висвітлення основних пріоритетів розвитку сучасної медичної освіти при ії̈ реформуванні, використання сучасних підходів до покращення підготовки високопрофесійних фахівців.

Основна частина. В університеті затверджена Концепція стратегічного розвитку Одеського національного медичного університету на період 2017-2020 рр., яка спонукає співробітників використовувати у своїй діяльності сучасні інноваційні технології. Перебудова медичної галузі в Україні потребує підготовки якісно нового лікаря, здатного поєднати в собі фундаментальні теоретичні знання 3 володінням сучасними інноваційними технологіями і практичними навичками [1]. Мова йде про необхідність впровадження в систему вищої медичної освіти компетентнісного підходу до підготовки фахівців. Цей метод не $є$ новиною: теоретичну підготовку, засвоєння навичок засобами симуляційних технологій на практичну підготовку на базі університетських клінік.
Відомо, що традиційна система навчання основана на отриманні знань, тоді як оцінка спеціаліста ведеться за критеріями вмінь та навичок. Сьогодні основна увага в медичній освіті приділяється компетентнісному підходу до навчання. Першочерговим досягненням цієї мети є впровадження програм, методологія яких навчає не просто знань, а знань та вмінь. Головну увагу треба приділяти методам активного навчання як найбільш дійовим та результативним [2, 3]. Тому у світлі актуальних проблем сучасної охорони здоров'я ми активно шукаємо нові шляхи щодо підвищення якості освіти, більш широко впроваджуємо перспективні новітні технології в структуру навчально-методичного процесу.

Формування компетентностей перш за все передбачає навчання практичних навичок на базі університетського Інноваційного центру практичної підготовки лікарів, у якому обладнання останнього слова техніки дозволяє навчати студентів і лікарів використовувати симуляційні технології - моделювання клінічних ситуацій різних рівнів складності, віртуальної реальності тощо.

Зараз на базі університету активно працює Навчально-інноваційний центр практичної підготовки лікарів та студентів (далі - Центр), обладнаний устаткуванням 31 до 7 рівнів реальності. Для пе-

() В. М. Запорожан, М. М. Каштальян, О. В. Чернецька 
ревірки компетентності та засвоєння виконання практичних навичок використовують брифінг, який полягає у презентації сценарію, та дебрифінг, під час якого студенти аналізують свої дії, оцінюють якість допомоги.

Особами, що можуть пройти навчання в Центрі, $\epsilon$ студенти вищих або середніх закладів медичної освіти, лікарі-інтерни, магістранти, лікарі-ординатори, аспіранти, практикуючі лікарі та робітники закладів охорони здоров’я, медичні сестри, фельдшери, акушери, немедичні працівники (співробітники служб цивільного захисту, члени рятувальних команд, військовослужбовці, охоронці, пожежники, моряки, робітники міліції, водії та інші). За 2 останні роки в Центрі пройшли навчання близько 1000 лікарів-курсантів різних спеціальностей і 5000 студентів та інтернів.

Організація навчання в Центрі здійснюється шляхом створення умов для самостійного виконання діагностичних та лікувальних маніпуляцій на тренажерах із застосуванням науково-педагогічного колективу та відбувається у вигляді тренінгів, які розрізняються залежно від аудиторії осіб, що навчаються, тематики та цілей. Це дозволяє формувати у студентів широке коло міцно закріплених практичних навичок без надання шкоди пацієнту, розвивати у майбутнього лікаря клінічне мислення, спроможність бездоганно виконувати більшість маніпуляцій і втручань, навчати роботи в команді та багато іншого.

Зараз заради підвищення професійного рівня майбутніх та працюючих лікарів розпочато створення симуляційних центрів на більшості профільних кафедр університету тому, що застосування симуляційних моделей та фантомів у навчанні задовольнить потреби досягнення їх певних компетенцій.

Активно використовуються технології сучасного навчання на післядипломному, фармацевтичному (заочна форма навчання) факультетах. Освітній простір вийшов далеко за межі кампусу і клінічних баз, розташованих у нашому місті. Корпоративна освітня мережа ОНМедУ включає два рівні: обласний і регіональний. Саме тому багатьма кафедрами університету активно використовуються технології відеоконференц-зв’язку для проведення семінарів і конференцій та спілкування з колегами. Основними інтерактивними підходами в системі навчання лікарів на післядипломному етапі є телемедичні проекти, інтерактивні лекції, вебінари, лекції в ре- жимі теперішнього часу з можливістю спілкування on-line, з розбором хворих за участю головних спеціалістів області та ін. Широко використовують вебінари як форму проведення інтерактивних навчальних занять через мережу “Інтернет” з використанням спеціального програмного забезпечення співробітники кафедри оториноларингології. Учасники такого семінару можуть не тільки слухати i дивитися те, що розповідає викладач, а й можуть ставити питання як у письмовій, так і в усній формі. Викладач має можливість демонструвати матеріали (слайди, сайти, текстові документи, робочий стіл свого комп’ютера тощо).

Перспективним напрямом діяльності факультету післядипломної освіти є проведення дистанційноочних курсів для провізорів. Для інформатизації університету необхідні технологічне забезпечення, створення інтерактивного навчального контенту i адаптивна система керування процесом навчання. Створення спільних освітньо-науково практичних кластерів, які б стали основою розробки новітніх лікувально-діагностичних технологій на базі доказової медицини та їх реального впровадження у практичну охорону здоров’я та на міжнародному рівні [2, 3].

На деяких кафедрах ОНМедУ (акушерства та гінекології № 1, внутрішньої медицини № 4, хірургічної стоматології тощо) застосовуються елементи дистанційного навчання в системі Moodle (Modular Object-Oriented Dynamic Learning Environment). На сервері дистанційного навчання викладачі можуть продемонструвати наочні матеріали у вигляді навчальних таблиць, презентацій лекцій, відеороликів. Це дозволяє підсилити інтерес студентів до навчального матеріалу, поліпшити засвоєння, а на практичному занятті найбільш оптимально використовувати відведений час, а також дозволяє сформувати і надати студенту організаційно-методичний та навчально-довідковий контент і забезпечує контроль самостійної діяльності студента. Зокрема, викладач може отримати інформацію про кількість відвідувань сервера, час перебування в електронному навчальному курсі, перелік оброблених ресурсів та елементів курсу, кількість і якість виконаних завдань. Така інформація дозволяє викладачам своєчасно впливати на навчальну діяльність студентів, корегувати проблеми у навчанні, а найголовніше - розвивати у студентів усвідомлення доцільності систематичної самостійної роботи. 
Поняття “інтерактивний” (від англійського “inter” - взаємний та “асt” - діяти) відповідає здатності до взаємодії та діалогу для серйозного вдосконалення і підвищення фахового рівня викладачів, можливість широкої та глибокої інтеграції наукових співробітників університету до Європейської наукової спільності. В умовах подальшого впровадження Європейської кредитно-трансферної системи (ЄКТС), яка орієнтує навчальний процес на результати навчання та компетенції студента, значно зросли вимоги до професійної компетентності науково-педагогічних працівників. В університеті введено підготовку до складання міжнародного іспиту Cambridge English Langlade Assessment - Level В2 як складової частини підготовки та атестації викладачів. Вільне знання англійської мови дозволить покращити якість навчально-педагогічного процесу та створить умови для збільшення мобільності викладачів.

Впровадження нових стандартів вищої освіти має стратегічне завдання з удосконалення системи контролю й оцінки якості освіти та вимагає порівняння досягнутого рівня освіти з новим еталоном, тобто стандартом освіти. Необхідним етапом переходу до нового покоління галузевих стандартів $\epsilon$ формування компетентнісного підходу на шляху підготовки сучасного фахівця. Перехід до компетентнісного підходу означає переорієнтацію 3 процесу навчання на результати освіти, зміщення акценту з накопичування знань, умінь і навичок на розвиток у здобувачів вищої освіти здатності практично діяти та застосовувати набутий досвід у конкретних ситуаціях. В основу системи державних стандартів вищої медичної освіти України покладений кардинальний принцип безперервного професійного розвитку лікарів упродовж усієї професійної діяльності.

Основним із пріоритетів розвитку сучасної освіти $є$ постійне вдосконалення навчально-методичних підходів до підготовки фахівців, внесення доповнень та змін до робочих навчальних планів і програм відповідно до потреб практичної охорони здоров'я.

Для якісної підготовки магістрів у галузі знань “Охорона здоров'я” до нового навчального року навчальним відділом ОНМедУ на основі примірних навчальних планів МОЗ України створені нові раціональні робочі навчальні плани з урахуванням принципу послідовного, логічного та сучасного викладання дисциплін у нашому медичному університеті.
У минулому навчальному році в ОНМедУ започатковано впровадження електронного журналу на 1-3 курсах. Використання електронного журналу обліку відвідування та успішності студентів має низку переваг. Надає швидкий доступ до результатів успішності студенту, викладачу та завідувачу кафедри, дозволяє оперативно інформувати деканати про оцінки студентів та швидко виявляти студентів з академічною заборгованістю. Студент самостійно може знайти тему пропущеного заняття або заняття, за яке отримав незадовільну оцінку, та відпрацювати їх. Чітка регламентованість внесення оцінок до електронного журналу знижує будь-яку вірогідність помилкового їх введення. Разом з тим ніхто не має змоги змінити поточну успішність студента, окрім самостійно перескладених незадовільних оцінок та пропусків занять, що забезпечує абсолютну прозорість навчального процесу.

Інтерактивні методи навчання з використанням сучасних комп'ютерних програм активно використовуються на всіх кафедрах університету у вигляді презентацій лекцій. Так, новітні інформаційні комп'ютерні технології, виконані у програмі Prezi, грунтуються на наближенні або віддаленні об'єктів, що робить лекцію не тільки більш видовищною, але й більш логічною, послідовною. Візуалізація презентації лекції за допомогою використання переходів від тексту до відеоматеріалів, графіків, карт, схем, таблиць, нестандартних завдань для самоконтролю та самоперевірки сприяє підвищенню ефективності такої лекції. Набуває практичного значення лекція - візуалізація, під час якої застосовуються демонстраційні матеріали (фотографії, відеофрагменти, відеофільми).

У даний час інтерактивні форми навчання з використанням цифрових технологій активно впроваджуються в навчальний процес. Так, для вивчення анатомії найбільш наочним $є$ проект 3D Medical Animations, створений Nucleus Medical Media inc. На порталі проекту зібрана величезна колекція 3D мультиплікації для студентів-медиків. На сайті можна знайти ілюстрації і схеми, які зроблені із застосуванням технологій 3D.

$€$ можливість на кафедрах проводити контроль знань у формі брейн-рингу. Питання готують не тільки викладачі, а й студенти або інтерни, поділені на команди. Ця форма контролю дозволяє не тільки оцінити рівень знань, швидкість реакції, але і виділити лідерів, які вміють організувати, згуртувати команду. 
Ефективним методом навчання $є$ клініко-реферативні конференції, на яких всі студенти старших курсів або інтерни представляють доповіді з мультимедійними презентаціями тривалістю 10 хв. Потім проблема обговорюється аудиторією і викладачами.

Застосування інтерактивних методів навчання в медичній освіті дозволяє навчати студентів вирішувати типові та нетипові ситуаційні завдання, поступово підводячи до творчості та прийняття правильних рішень.

Кафедри офтальмології і гістології, цитології та ембріології ОНМедУ використовують, крім кейсметоду, “мозкового штурму”, ще й технологію “Mind Mapping”, тобто візуалізацію складних процесів за допомогою графічного зображення.

Проблеми реформування охорони здоров'я лежать не тільки в економічній площині. Головною дійовою особою і гарантом усіх медичних реформ $€$ лікар.

Сучасний лікар має володіти інноваційними технологіями діагностики і лікування, технікою ендоскопічних, малоінвазивних, реконструктивно-пластичних втручань тощо. А для цього студент повинен вчитися у найкращих хірургів, які виконують високотехнологічні операції у відповідно оснащених операційних, до яких студент мав би доступ. Саме тому в країнах Європи, Америки, навіть у Росії при вищих медичних навчальних закладах існують університетські клініки.

Практика сьогодення така, що в більшості медичних вузів України клінічні кафедри розташовані на базі міських лікувальних закладів, стан яких за своїм матеріальним оснащенням не відповідає вимогам навчальних баз. Лікаря завтрашнього дня неможливо готувати на обладнанні дня вчорашнього. Крім того, навчання майбутнього лікаря на базі “чужого" лікувального закладу не забезпечує його практичної підготовки, тому що ані викладач, ані студент не мають доступу до операційних, лабораторій, діагностичних центрів тощо. До того ж муніципальні лікарні не мають не тільки функціонального обов'язку, але й навичок навчання студентів. А сьогодні йде мова про те, що університети ще й повинні сплачувати за оренду приміщень міських клінік та комунальні послуги. Насправді це нонсенс, тому що медичні університети готують спеціалістів для соціальної сфери, їх професорсько-викладацький склад надає мешканцям міста висококваліфіковану медичну допомогу.
Університетська клініка - це унікальне поєднання медичної освіти, науки і практики, де налагоджено нерозривний ланцюжок від ідеї до її наукової розробки та практичного втілення, і при цьому відбувається підготовка висококласних медичних кадрів.

Нам вдалося створити три власні клініки, на базах яких працюють 15 клінічних кафедр університету. А наприкінці 2014 року нашому ВН3 повернули всі клініки медичного містечка, відібрані в нас у 60-ті роки. Нині університетські клініки ОНМедУ мають у своєму розпорядженні близько тисячі ліжок. Одна 3 них (багатопрофільна) є медичним закладом третього рівня, у якому надається високотехнологічна допомога. Фахівці цієї клініки використовують медичні технології і проводять операції, частина з яких не має аналогів в Україні.

Досвід роботи університетської клініки переконливо довів доцільність основної ідеї ї̈ роботи - клінічне впровадження найновіших технологій і інтелектуальних досягнень, які відпрацьовуються i впроваджуються метрами лікувальної професії одночасно $з$ навчальним процесом. У клініці унікально поєднуються дипломна і післядипломна підготовка лікаря, наукова робота і надання висококваліфікованої медичної допомоги. При цьому навчання й лікувально-діагностична робота здійснюються 3 використанням найсучаснішої медичної апаратури і новітніх медичних технологій із залученням висококваліфікованих фахівців різних профілів.

Покращення якості підготовки фахівців відповідно до вимог сучасного ринку праці, конкурентоспроможних в Україні та на міжнародному рівні, потребує модернізації навчально-виховного процесу, спрямування його на створення оптимальних умов для їх професійного становлення.

Закуплено обладнання для створення в університеті унікальної сучасної лабораторії молекулярногенетичних технологій, яка буде обслуговувати як теоретичні, так і клінічні кафедри. Заняття зі студентами буде проводитися в режимі on-line, а інтерпретація результатів обстеження, встановлення діагнозу здійснюються викладачем та транслюються в необхідних аудиторіях. Можливості використання сучасного обладнання для лабораторних досліджень створять у студентів мотивацію щодо навчання, оскільки отримані теоретичні знання знайдуть широке застосування у практичній діяльності.

Заплановано закупку унікального обладнання для створення міжнародного рівня міжкафедральних найсучасніших операційних ароботичної хірургії 
3 гібридною операційною. Це значно підвищить технологічність наших клінік, діагностичну, лікувальну роботу, їх конкурентоспроможність.

Підтвердженням того, що в університеті ведеться безперервна копітка робота з покращення якості освіти, є значна кількість нагород на міжнародних і регіональних виставках. Так, ОНМедУ взяв участь у Першій міжнародній професійній виставці з питань освіти 3НО-2016 (Київ) й отримав там нагороди - гран-прі у номінаціях “Лідер інновації у діяльності навчального закладу “університет-новатор”, “Лідер інновації у розвитку міжнародної співпраці та презентації національної освіти у світовому та європейському освітньо-науковому просторі” та "Високий стиль сучасних програм, інноваційних підходів для підвищення якості освіти в контексті цивілізаційних змін”.

Висновки. Реформування медичної освіти спрямовано на підвищення якості освітнього процесу,

\section{Список літератури}

1. Про вищу освіту : Закон України від 01.07.2014 p. № 1556-VII.

2. Перспективи впровадження сучасних інновацій в освітню діяльність університету / В. М. Запорожан,

\section{References}

1. Pro vyshchu osvitu: zakon Ukrainy vid 07.07.2014 r. $N$ 1556-VII [Higher educational Act of Ukraine] of July 1, 2014 N 1556-VII [in Ukrainian].

2. Zaporozhan, V.M., Kresiun, V.Y., Rohachevskyi, O.P., \& Chernetska, O.V. (2016). Perspektyvy vprovadzhennia suchasnykh innovatsii v osvitniu diialnist [Prospects

Електронна адреса для листування: kashtalyn_m@mail.ru що спонукає використовувати різні сучасні підходи до покращення підготовки високопрофесійних фахівців. Науково-педагогічні співробітники ОНМедУ у своїй діяльності керуються Концепцією стратегічного розвитку університету на період 2017-2020 pp.

Серед першочергових завдань щодо модернізації системи підготовки медичних кадрів вважаємо наступне:

1. Обов'язкове створення в кожному вищому медичному навчальному закладі університетської клініки та симуляційного центру.

2. Вирішити законодавчо питання щодо безкоштовного розміщення клінічних кафедр університетів на базі обласних і міських лікувальних закладів.

3. Забезпечити імплементацію в повному обсязі всіх можливостей, передбачених Законом “Про вищу освіту”, щодо автономії університетів.

В. Й. Кресюн, О. П. Рогачевський, О. В. Чернецька // Медична освіта. - 2016. - № 3. - С. 73-77.

3. Валерій Миколайович Запорожан: Творчий шлях / [упоряд. Г. І. Хандрікова]. - Одеса : ОНМедУ, 2017. C. 224.

for modern innovations implementation into learning activity]. Medychna osvita - Medical education, 3, 73-77 [in Ukrainian].

3. Khandrikova, H.I. (ed.) (2017). Valerii Mykolaiovych Zaporozhan: Tvorchyi shliakh [Valerii Mykolaiovych Zaporozhan: Creative Development]. Odesa: ONMedU [in Ukrainian]. 